\title{
IJBF EFFICIENCY OF DOMESTIC AND FOREIGN BANKS IN THAILAND SINCE THE ASIAN FINANCIAL CRISIS
}

\author{
Tosporn Chotigeat \\ Nicholls State University, United States
}

\begin{abstract}
During the 1990's, two simultaneous phenomena had converged, greatly changing the financial services industry in Thailand. At the national level, Thai banks had to restructure in response to the financial reforms implemented as a result of the financial crisis of 1997. At the global level, large multinational banks were taking advantage of worldwide, financial deregulation and rapid technological advances by offering a full range of financial products and services in order to fiercely compete, both domestically and globally. Using quarterly financial time-series data of domestic and foreign banks in Thailand from 1997 to 2003, this paper seeks to analyze the cause of their efficiency. The findings indicate that both the efficiency ratio and loan loss provisions influenced the negative performance of domestic banks, while only loan loss provisions had negatively influenced the performance of foreign banks.
\end{abstract}

Keywords: Efficiency, Domestic/foreign banks, Loan loss provision, ROE, Financial crisis

JEL Classification: C32, E44, F23, G15

\section{Introduction}

Since the Asian financial crisis ten years ago, two simultaneous phenomena had converged to greatly change the financial services industry landscape, both at the regional and global level. In the wake of the crisis, those afflicted countries had adopted (whether voluntarily and/or under pressure from the IMF and other international agencies) new policies emphasizing high levels of transparency and the liberalization of capital markets. At the same time, major players in the global financial services sector have continued leveraging advances in telecommunications and information technology, while increasing the amount of cross-border mergers and acquisitions. This has led to an intensified increase of competition, both in the crisis countries and in the rest of the world. At this point, the question then arises as to whether or not these domestic banks and foreign banks are equally competitive; and if not, what are the salient factors that have contributed to the differentiation in their respective levels of performance. 
Since 2000, with restructuring near completion of the Thai financial sector, the economy had experienced a successful recovery with favorable key economic indicators, both internally and externally, displaying a comfortable level of stability. (Appendix A). Thus, domestic and foreign banking operations have been selected for this study, for they offer the best scope regarding the health and stability of the financial sector in a post-crisis Thailand. This paper attempts to empirically investigate and compare each group's performance by using quarterly data from 1997 to 2003. Section 2 will provide a background description of Thai commercial banks and their evolution since the financial crisis, as well as an analysis of the global integration of the Thai markets with an increased international competition in the financial services industry. Section 3 will review the literature related to banks' performance in various countries, while the model and time-series data being used to test the efficiency of banks will be provided in Section 4 with great detail. Lastly, the empirical results and conclusions will be provided in the remaining two sections.

\section{Background}

\subsection{Reorganization of the Thai Financial Sector After the Crisis}

Immediately after the financial crisis of 1997, the Thai government had closed down 64 of its 91 domestic financial companies, leaving only 27 open with 13 local banks in operation. Those remaining banks and financial companies were allowed to create 300 billion baht for new capitalization by issuing preferred shares and new debt debentures in exchange for 10-year government bonds. Financial institutions were also required to increase their reserve funds for the existing large non-performing loans (NPLs) (see Bangkok Post, 1999]. Although the NPLs were reduced to 12.65 percent by the end of 2003, they still continue to burden the financial system in 2007.

In addition, the Financial Sector Restructuring Authority (FRA) and Asset Management Corporation (AMC) were created to handle the assets of now defunct financial companies. The FRA seized the assets of defunct financial companies and banks, then selling them at an average bid of 37 percent of book value. The process was very slow with many assets lacking the full, proper, and official documentation. By the end of 2003, there were only 13 domestic commercial banks and 18 foreign banks operating in Thailand.

\subsection{Global Synergy \& International Competition of the Financial Services Industry}

Since the inception of a global integration, international competition in the financial services industry around the world has greatly intensified. During the last 20 years, only a few firms have swiftly advanced their cause like that of the banking industry. The competitive sector in which they had competed took advantage of the financial deregulations and rapid technological advances worldwide in the 1990s. With deregulation removing the regulatory barriers to entry and technological advances reducing the cost of managing affiliates in distant markets, banks had undertaken a 
strategy of growth by merger \& acquisition to accomplish two objectives:

- $\quad$ defend a position within their domestic stronghold by merging with other domestic competitors, thereby fending off potential foreign competitors

- establish presence in foreign markets by acquiring interest in foreign institutions $^{1}$

While the extent of the industry's outreach into the global arena through international acquisitions is debatable, ${ }^{2}$ what is clear is the full effect of deregulation and technological advances (i.e., cross-border, mega-size mergers \& acquisitions recently undertaken by multinational banks). The large multinational banks now offer a full range of financial products and services, fiercely competing in both the domestic and global markets.

\section{Bank Performance Literature on Other Countries}

Many specialists have a mixed point of view on the effects of deregulation and technological advances. For US banks, Berger \& Mester (2003) found that cost productivity worsened even though profit margins substantially improved for banks engaging in mergers. Focarrelli and Pozzolo (2001) and Williams (2003) had evaluated the profitability of international banks in the OECD, as well as that of domestic and foreign banks in Australia, respectively. Both studies had argued that efficient banks expand abroad seeking higher profits, but that profits are negatively correlated to their market share. Using Italian data, Focarelli, Panetta, and Salleo (2002) had shown that mergers increase income from expanded services and product lines, but the increase is offset by higher costs. However, the return on equity improves because of a decrease in the capital base of the acquiring bank.

Similar studies of commercial banks in other countries have been undertaken, i.e., studies of Japanese banks by Drake \& Hall (2003); Indian banks by Kumbhakar and Sarkar (2003); Portuguese banks by Mendes and Reblo (1999); Turkish banks by Isik and Hassan (2003); and Spanish banks by Grifell-Tatje and Lovell (1996). While the analytical designs and econometric variables used in these studies had considerably varied, one common theme had emerged: following the deregulation or technological change, the measures of profitability and/or productivity had generally declined for banks in these diverse countries.

\section{Measure of Global Bank Performance and Determinants}

Properly gauging all aspects of profitability is a generally accepted way to measure the performance of businesses, specifically commercial banks. However, banks vary considerably in terms of size, types of products offered, and types of assets

1 See Larosiere (2000) for an excellent discussion on banking consolidation in Europe and why most European banks favor merger and acquisition for their growth.

2 Examining how more than 2,000 affiliates of large MNC's patronize banks in 20 European nations, Berger, Dai, Ongena and Smith (2002) argue that the banking industry may never become fully globalized. 
owned, among many other factors. Therefore, some standard form of measuring profitability is needed. Two potential measures of bank performance are return on assets (ROA) and return on equity (ROE). Due to the nature of bank assets (largely loans), ROE seems to be the more appropriate measure, at least from a purely logical perspective. For that very reason, ROE is used as the dependent variable for this analysis. Finally, regression analysis is the generally accepted tool for measuring the relationship among variables.

Similar studies of international banks have used five variables (total assets, efficiency ratio, Tier1 capital ratio, loan loss provisions, and non-interest income) to explain bank performance, as noted by the likes of Allen and Raj (1996), Kim and Singer (1997), and Brimmer (1998). For purposes of comparing Thai domestic banks and foreign banks in Thailand, this analysis follows similar lines. Efficiency can be defined as the ratio of a given bank's non-interest expense to total revenue. It is hypothesized that the coefficient of this variable will be negative because higher ratios imply the reduced efficiency of bank operations. Second, a measure of risk was ascertained by calculating the ratio of Tier1 capital to risky assets. The Tier1 capital ratio is defined as core capital (essentially the book value of a bank's equity) divided by risk-adjusted assets (basically total assets, weighted more heavily for more risky assets). The coefficient of the Tier1 capital ratio is hypothesized to be negative. Thirdly, loan loss provisions are used to represent bad debts. Here a negative coefficient for the variable is anticipated since increases in the loan loss provisions suggest that the quality of the bank's loan portfolio is reduced. The non-interest income variable is expected to have a positive impact on a bank's performance. Finally, the total asset value is considered as the other potential explanatory variable, but the coefficient is not expected to produce statistically significant results.

An empirical study done by Grosse and Gart (2001) reports that there are considerable variations in the key factors that influence the performance of multinational banks from different countries. For American banks, efficiency is the only significant variable, whereas, for UK banks, total assets, efficiency, and loan loss provisions are significant. For German banks, the total assets and noninterest income are significant, whereas the efficiency and Tier1 capital ratio are significant for Japanese banks. Surprisingly, none of these variables were found to be a significant determinant for the performance of Swiss banks.

From 1993 to 1999, Chotigeat et al. (2004) had empirically studied the performance of the following three major French banks: Societe General, BNP Paribus, and Credit Lyonnais. It was found that the factors determining the banks' profit are total assets, efficiency, Tier1 capital ratio, and loan loss provisions.

\section{Data and Model}

For this study, all commercial banks that operate in Thailand were selected (i.e., 13 Thai domestic banks and 18 foreign banks). The data used originates from the quarterly reports of the Bank of Thailand from 1997 to 2003, a period in which:

- Thailand reconstructed its financial system after the financial crisis of July 1997 , 
which included a policy of transparency and capital market liberalization

- $\quad$ there were significant cross-border investments taking place in the world's banking industry.

The six, key variables calculated from the raw time-series data to be used in this study are: return on assets (ROA), return on equity (ROE), total assets, efficiency ratio (non-interest expense to total revenue), the Tier1 capital (equity capital divided by adjusted-risk assets), loan loss provisions, and non-interest income.

\subsection{The Model}

The least-square model used to measure a bank's performance is expressed as:

$\mathrm{ROE}_{\mathrm{it}=} \alpha+\beta_{1} \mathrm{ASST}_{\mathrm{it}}+\beta_{2} \mathrm{EFF}_{\mathrm{it}}+\beta_{3} \mathrm{TIER}_{\mathrm{it}}+\beta_{4} \mathrm{NII}_{\mathrm{it}}+\beta_{5} \mathrm{LLP}_{\mathrm{it}}+\varepsilon_{\mathrm{it}}$

where,

ROE $=$ the return on equity, $\quad$ LLP $=$ loan loss provisions.

ASST $=$ total assets,

TIER1 = Tier1 capital ratio,

$\mathrm{EFF}=$ efficiency ratio,

NII = non-interest income, and $\varepsilon_{\mathrm{it}}($ error term $) \sim \mathrm{N}\left(0, \sigma^{2}\right)$.

\section{Empirical Results}

Table 1 provides the performance of domestic and foreign banks in Thailand. Foreign banks perform better than domestic banks in terms of total income (both interest income \& non-interest income) and pre-tax profit, even though foreign banks had higher operating costs and loan loss provisions. In fact, domestic banks earned a negative value in pre-tax profit. The domestic banks' poor performance reflects the impact felt by the Thai financial crisis of July 1997 and its aftermath of adopting new, liberal financial policies.

Table 1: Performance of Thai Banks vs. Foreign Banks in Thailand, Major U.S. Banks, and European Banks (in percent)

\begin{tabular}{lccccccc}
\hline & $\begin{array}{c}\text { Thailand } \\
\text { (Domestic) }\end{array}$ & $\begin{array}{c}\text { Thailand } \\
\text { (Foreign) }\end{array}$ & U.S.* & $\begin{array}{c}\text { Euro } \\
\text { Zone* }\end{array}$ & France* & Spain** & U.K.* \\
\hline $\begin{array}{l}\text { 1. Net interest } \\
\text { margin }\end{array}$ & 1.60 & 4.88 & 3.22 & 1.68 & 0.93 & 2.66 & 2.19 \\
$\begin{array}{l}\text { 2. Non-interest } \\
\text { income }\end{array}$ & 1.04 & 3.08 & 2.65 & 1.19 & 0.89 & 1.36 & 1.75 \\
$\begin{array}{l}\text { 3. Total income: } \\
\quad(1)+(2)\end{array}$ & 2.64 & 7.96 & 5.87 & 2.87 & 1.82 & 4.02 & 3.98 \\
$\begin{array}{l}\text { 4. Operating cost } \\
\begin{array}{l}\text { 5. Loan loss } \\
\text { provision }\end{array}\end{array}$ & 2.24 & 3.96 & 3.80 & 1.98 & 1.26 & 2.67 & 2.59 \\
$\begin{array}{l}\text { 6. Pre-tax profit: } \\
\text { (3)-(4)-(5) }\end{array}$ & 2.48 & 2.56 & 0.39 & 0.31 & 0.24 & 0.39 & 0.22 \\
\hline
\end{tabular}

*Data covered 1996-98 from Larosiere (2000). 
Table 2 compares and presents the mean values of the key factors (i.e., ROE, ROA, efficiency ratio, loan loss provisions/total assets, and Tier1 capital ratio) that affect bank performance. Clearly, Thai banks show negative values for both ROE and ROA, whereas they have a higher ratio of loan loss provision to total assets. On the contrary, foreign banks in Thailand perform better. Their key factors are all in small positive values, yet, they still did not meet the banking industry's standard measure of good performance:i.e., ROA $>1$ (Ritter et al. (2000, p. 225). In fact, only a handful of banks worldwide have their ROA $>1$, such as, Lloyds and Chase Manhattan (Chotigeat et al. 2004).

Table 2: Performance Data for Thai Banks and Foreign Banks in Thailand

\begin{tabular}{cccccc}
\hline & ROE & ROA & $\begin{array}{c}\text { Efficiency } \\
\text { ratio }\end{array}$ & $\begin{array}{c}\text { Loan loss } \\
\text { provisions/ } \\
\text { total assets }\end{array}$ & $\begin{array}{c}\text { Tier 1 } \\
\text { capital }\end{array}$ \\
\hline $\begin{array}{c}\text { Thai banks } \\
(1997-2003)\end{array}$ & -.24 & -0.02 & -0.01 & 0.03 & 0.28 \\
\hline $\begin{array}{c}\text { Foreign-Branch Banks in } \\
\text { Thailand } \\
(1997-2003)\end{array}$ & 0.12 & 0.31 & 0.12 & 0.01 & 0.38 \\
\hline
\end{tabular}

Table 3 provides a matrix of correlation coefficients among the variables being used in equation (1).

Table 3: Correlation Coefficient Matrix

\begin{tabular}{lcccrrr}
\hline \multicolumn{7}{c}{ Panel $\boldsymbol{A}$. Thai Commercial Banks } \\
\hline EFF & ASST & TIER1 & ROE & NII & LLP \\
\hline EFF & 1.00 & -0.16 & -0.10 & -0.40 & 0.09 & 0.05 \\
ASST & -0.16 & 1.00 & -0.56 & 0.36 & 0.44 & -0.40 \\
TIER1 & -0.10 & -0.56 & 1.00 & -0.29 & -0.17 & 0.35 \\
ROE & -0.40 & 0.36 & -0.29 & 1.00 & 0.33 & -0.66 \\
NII & 0.09 & 0.44 & -0.17 & 0.33 & 1.00 & -0.35 \\
LL & 0.05 & -0.40 & 0.35 & -0.66 & -0.35 & 1.00 \\
\hline & Panel B. & Foreign-branch banks in Thailand & & \\
\hline & EFF & ASST & TIER1 & ROE & NII & LLP \\
EFF & 1.00 & -0.06 & -0.12 & 0.27 & 0.16 & 0.01 \\
ASST & -0.06 & 1.00 & -0.67 & -0.11 & 0.05 & 0.45 \\
TIER1 & -0.12 & -0.67 & 1.00 & 0.05 & 0.23 & -0.47 \\
ROE & 0.27 & -0.11 & 0.05 & 1.00 & 0.17 & -0.55 \\
NII & 0.16 & 0.05 & 0.23 & 0.17 & 1.000 & 0.01 \\
LLP & 0.011 & 0.45 & -0.47 & -0.55 & 0.01 & 1.00 \\
\hline
\end{tabular}


In each panel, only one of the coefficients (in absolute value) is greater than 0.50. The correlation coefficient between total assets and Tier1 capital ratio for Thai commercial banks is -0.56 , respectively, while for foreign banks in Thailand, the correlation coefficient for the same relationship is -0.67 , respectively. To avoid multi-collinearity issues, we chose not to use both the total assets and Tier1 capital ratio at the same time in an equation. Thus, we formulated two models: Model 1 has total assets, efficiency, Tier 1 capital, loan loss provision, and non-interest income as the independent variables, while Model 2 is the same as Model 1 without the variable of total assets.

Table 4: Results from Regression Model 1

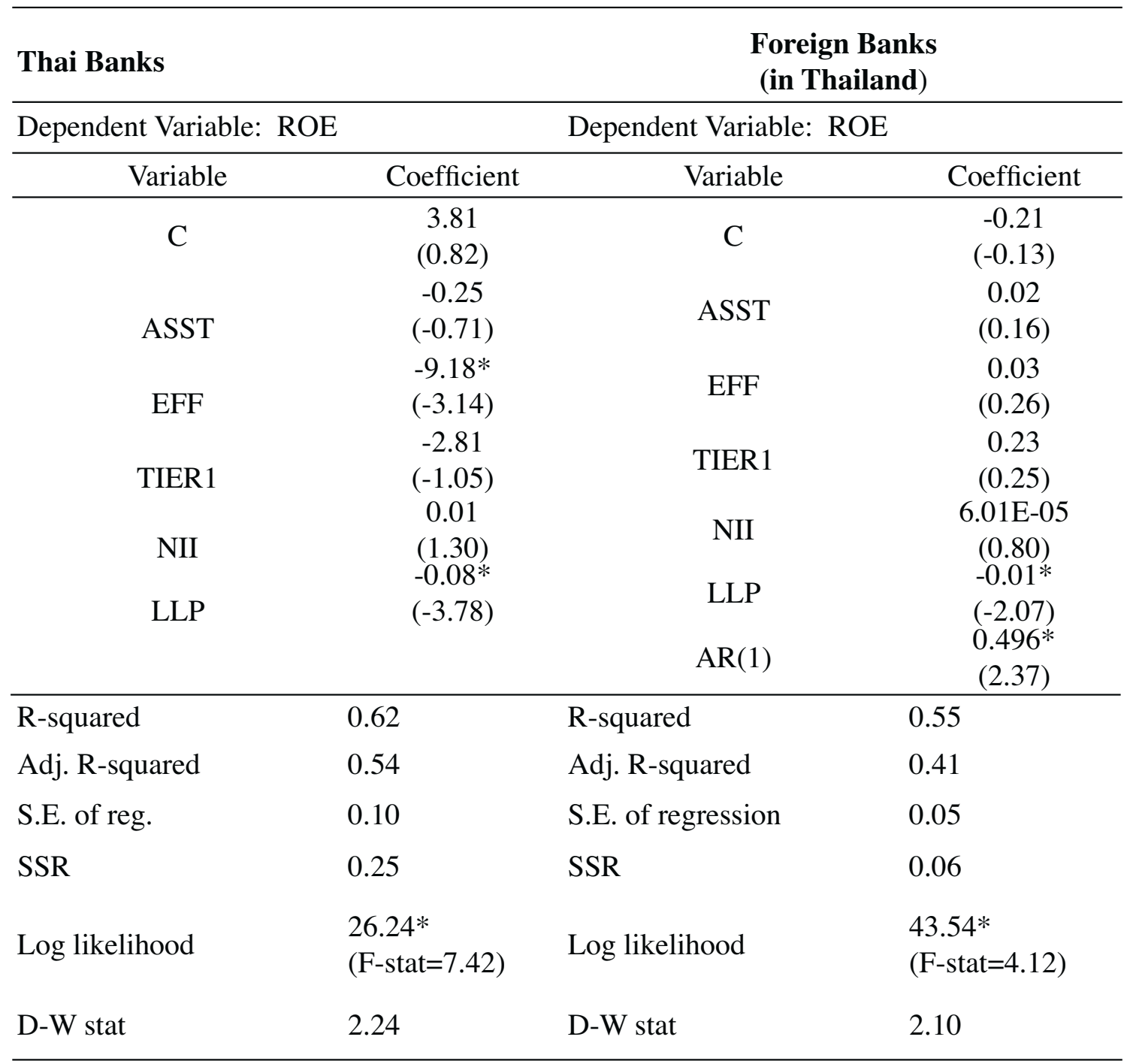

$t$-stat is in parenthesis; $* 1 \%$ significance level; ** $5 \%$ significance level

The LS regression model of equation (1) was estimated for Model 1 with the estimated parameters provided in Table 4. In the left two columns of Table 4, the coefficients show that Thai domestic bank performance is statistically influenced negatively by only two variables: the efficiency ratio and loan loss provision. The 
two coefficients have the appropriate signs in relation to the hypotheses postulated. For coefficients of the other three variables (total assets, Tier1 capital ratio, and non-interest income), each has an appropriate sign, yet they are not statistically significant. Overall, all the estimated parameters conform to the hypothesis in terms of sign, but only two were found to be statistically significant.

The right two columns of Table 4 provide the estimated coefficients of foreign banks in Thailand. The model was modified to correct the autocorrelation of the error-term in the model; thus, the specification of equation (1) that includes AR (1) is appropriate. Only the coefficient of loan loss provision shows a negative sign (as was expected) whose significance is statistically viable. The coefficient of non-interest income has an appropriate positive sign, but it is not statistically significant.

Table 5 provides the estimated parameters of Model 2 (again, Model 1 without the total assets variable). The pattern of coefficient estimates has not changed for Thai domestic banks, nor has it for foreign banks operating in Thailand.

Table 5: Regression Model 2

\begin{tabular}{|c|c|c|c|}
\hline \multirow{2}{*}{$\begin{array}{l}\text { Thai Bank } \\
\text { Variable }\end{array}$} & \multirow[b]{2}{*}{ Coefficient } & \multicolumn{2}{|c|}{$\begin{array}{l}\text { Foreign Bank } \\
\text { (in Thailand) }\end{array}$} \\
\hline & & Variable & Coefficient \\
\hline $\mathrm{C}$ & $\begin{array}{l}0.52 * \\
(2.26)\end{array}$ & $\mathrm{C}$ & $\begin{array}{c}0.04 \\
(0.48)\end{array}$ \\
\hline EFF2 & $\begin{array}{l}-8.48^{*} \\
(-3.11)\end{array}$ & EFF2 & $\begin{array}{c}0.02 \\
(0.24)\end{array}$ \\
\hline TIER1M & $\begin{array}{l}-1.76 \\
(-0.80)\end{array}$ & TIER1M & $\begin{array}{c}0.13 \\
(0.17)\end{array}$ \\
\hline NIIN & $\begin{array}{c}0.01 \\
(1.12)\end{array}$ & NIINM & $\begin{array}{c}6.32 \mathrm{E}-05 \\
(0.90)\end{array}$ \\
\hline \multirow[t]{2}{*}{ LLP } & $\begin{array}{l}-0.07 * \\
(-3.76)\end{array}$ & LLPM & $\begin{array}{l}-0.01 * \\
(-2.18)\end{array}$ \\
\hline & & $\mathrm{AR}(1)$ & $\begin{array}{l}0.49 * \\
(2.79)\end{array}$ \\
\hline R-squared & 0.61 & R-squared & 0.55 \\
\hline Adj. R-squared & 0.55 & Adj. R-squared & 0.44 \\
\hline S.E. of regression & 0.10 & S.E. of regression & 0.05 \\
\hline SSR & 0.25 & SSR & 0.06 \\
\hline Log likelihood & $\begin{array}{l}25.9 * \\
(\mathrm{~F}-\text { stat }=9.34)\end{array}$ & Log likelihood & $\begin{array}{l}43.51 * \\
(\mathrm{~F}-\mathrm{stat}=5.18)\end{array}$ \\
\hline D-W stat & 2.11 & D-W stat & 2.11 \\
\hline
\end{tabular}

$t$-stat is in parentheses; * $1 \%$ significance level; ** 5\% significance level 
Our findings are consistent with those found in other countries that were reported in other studies. ${ }^{3}$ The determinants of the Thai domestic banks and foreign banks in Thailand are compared to those of other top banks around the world (see Table 6).

For Thai domestic banks, the significance of the efficiency ratio is similar to that of Japanese, British, American, and French banks; loan loss provision is similar to that of British and French banks. For foreign-branch banks in Thailand, loan loss provision is similar to that of British, French, and Thai domestic banks.

Table 6: Determinants of Efficiency: Individual Country Banks Comparison

\begin{tabular}{lccccccc}
\hline & $\begin{array}{c}\text { Thai } \\
\text { (Domestic) }\end{array}$ & $\begin{array}{c}\text { Foreign } \\
\text { (in } \\
\text { Thailand) }\end{array}$ & France & USA & UK & Germany & Japan \\
\hline Total assets & & & $\mathrm{X}$ & & $\mathrm{X}$ & $\mathrm{X}$ & \\
$\begin{array}{l}\text { Efficiency } \\
\begin{array}{l}\text { Tier1 capital } \\
\text { ratio }\end{array}\end{array}$ & $\mathrm{X}$ & $\mathrm{X}$ & $\mathrm{X}$ & $\mathrm{X}$ & & $\mathrm{X}$ \\
$\begin{array}{l}\text { Loan loss } \\
\text { provisions }\end{array}$ & $\mathrm{X}$ & $\mathrm{X}$ & $\mathrm{X}$ & & $\mathrm{X}$ & & \\
$\begin{array}{l}\text { Non-interest } \\
\text { income }\end{array}$ & & & & & & & \\
\hline
\end{tabular}

(X indicates a statistical significance of the coefficient.)

Source: Chotigeat et al. (2004, p. 14).

Overall, our findings confirm the previous studies that efficiency and loan loss provision are the dominant factors that determine the profit performance of banks worldwide. For foreign banks, despite the fact that they...

- $\quad$ are from different countries

- operate under different banking systems under different organizational structures

- $\quad$ have different corporate cultures

- $\quad$ operate under varying national economies,

they still share many common variables with global competitors from around the world.

\section{Conclusion}

With new, financial systems that emphasize \& enforce a policy of liberalization \& transparency, many foreign banks are now seeking to operate in Thailand. What

3 Focarelli, Panetta and Salleo (2002); Grifell-Tatje and Lovell; and Kumbhakar andh Sarkar 
is of great interest is how Thai banks had performed after the crisis and how their performance compared to that of foreign banks that operated in the same environment in Thailand. Their performance (specifically, the value of the ROE capital ratio) was negatively influenced by the efficiency ratio and loan loss provisions, where each negative sign confirms our hypothesis. For the foreign banks in Thailand, only the loan loss provision factor confirms our hypothesis (negative sign) as a determinant of performance.

When we compared the determinants of performance for both groups in this study with those of other top banks around the world, we found that the significance of efficiency for the Thai banks' performance is similar to that of French, US, British, and Japanese banks. The loan loss provision is similar to that of French, British, and other foreign banks in Thailand.

Lastly, foreign banks in Thailand only have loan loss provisions as their determinant, which is similar to that of French and British banks. On balance, loan loss provision is the only common factor that is applicable to the performance evaluations of the Thai domestic banks and foreign banks operating in Thailand. Globally, efficiency, total assets, and loan loss provisions are the three determinants of banks' performance. We think foreign banks may have an edge over domestic Thai banks because foreign banks have recognized the competitive intensity of the financial services business. Simply put, multinational banks worldwide have had to react to the changing business environments brought forth by global deregulation by increasing their M\&A activity. Therefore, Thai domestic banks could possibly benefit by learning form their foreign counterparts.

Author statement: Tosporn Chotigeat, Department of Economics and Finance, Nicholls State University. E-mail: ecfi-tc@nicholls.edu. He is the editor of the Global Business and Finance Review.

\section{References}

Allen, Linda, and Annop Rai. 1996. Operational Efficiency in Banking: An International Comparison. Journal of Banking \& Finance, 20: 655-672. (Bangkok Post. 1999. "The 1999 Mid-Year Economic Review.” July.

Berger, Allen N., Qinglei Dai, Steven Ongena, and David C. Smith. 2002. To What Extent Will the Banking Industry Be Globalized? A Study of Bank Nationality and Reach in 20 European Nations. Journal of Banking \& Finance, 27, 383415.

Berger, Allen N., and Loretta J Mester. 2003. Explaining the Dramatic Changes in the Performance of U. S. Banks: Technological Change, Deregulation, and Dynamic Changes in Competition. Journal of Financial Intermediation, 12, 57-95

Brimmer, Andrew. 1998. Competition and the Integration of the Markets for Banking and Financial Services. North American Journal of Economics and Finance, 9: 187-202. 
Cabral, Ines, Frank Dierick, and Iukka Vesala. 2002. Banking Integration in the Euro Area. Occasional Paper No. 6, European Central Bank

Chotigeat, T., Sebastien Kramer, and C.S. Pyun. 2004. Efficiency and Resilience of French Multinational Banks: Evidence From the Pre-Euro Era, Multinational Business Review, 12-1, 3-17.

Drake, Leigh, and Maxmilan J. B. Hall. 2003. Efficiency in Japanese Banking: An Empirical Analysis, Journal of Banking and Finance, 27, 891-917. The Economist, Feb 2, 2002, "Deutsche's American Dream ', pp. 69-70.

Focarelli, Dario, Fabio Panetta and Carmelo Salleo. 2002. Why Do Banks Merge? Journal of Money, Credit, and Banking, 34-4, 1047-1066.

Focarelli, D., and A. Pozzolo. 2001. The Pattern of Cross-Border Bank Margin and Shareholdings in OECD. Journal of Banking and Finance, 25, 2305-2337.

Goldberg, Lawrence, and Gerald Hanweck. 1991. The Growth of the World's 300 Largest Banking Organizations by Country. Journal of Banking \& Finance, 15: 207-223.

Grifell-Tatje, E., and C. A. K. Lovell. 1996. Deregulation and Productivity Decline: The Case of Spanish Savings Banks. European Economic Review, 40, 12811303.

Grosse, Robert, and Alan Gart. 2001. International Banks' Performance: A FiveCountry Comparison. Global Business and Finance Review, 6(2): 1-15.

Isik, Ihsan, and M. Kabir Hassan. 2003. Financial Deregulation and Total Factor Productivity Change: An Empirical Study of Turkish Commercial Banks. Journal of Banking and Finance, 27, 1445-1485.

Kim, Seung, and Robert Singer. 1997. US and Japanese Banks: A Comparative and Evaluative Analysis. The Bankers Magazine, March-April, 56-61.

Kumbhakar, Subal C., and Subrata Sarkar. 2003. Deregulation, Ownership, and Productivity Growth in the Banking Industry: Evidence from India. Journal of Money Credit and Banking, 35, 403-424.

Larosiere, Jacqueo de. 2000. Banking Consolidation in Europe, the Per Jacobson Foundation Lecture Series. Bank for International Settlement, Lucerne, Switzerland, 18-44.

Mendes, V., and J. Reblo. 1999. Productive Efficiency, Technological Change and Productivity in Portuguese Banking, Applied Financial Economics, 9, 513521.

Pindyck, Robert S., and Daniel L. Rubinfeld, 1991. Econometrics Models \& Economic Forecasts, $3^{\text {rd }}$ edition, New York: McGraw-Hill Inc.

Ritter, L.S., W.L. Silber, and G.F. Udell. 2000. Money, Banking, and Financial Markets. $10^{\text {th }}$ Edition. New York: Addison-Wesley.

Sanford, Charles. First Quarter 1994. Financial Markets in 2020. Economic Review. Kansas City: Federal Reserve Bank of Kansas City, 19-28.

Spiegel, John, Alan Gart, and Steven Gart. 1996. Banking Redefined. Chicago: Irwin.

Williams, Barry. 2003. Domestic and International Determinants of Bank Profits: Foreign Banks in Australia. Journal of Banking and Finance, 27, 11851210. 


\section{Appendix A}

\begin{tabular}{|c|c|c|c|c|c|c|}
\hline \multicolumn{7}{|c|}{ Key Economic Indicators of Thailand (1997-2003) } \\
\hline \multicolumn{7}{|c|}{ Internal Balance } \\
\hline Country & Year & $\begin{array}{c}\text { GDP } \\
\% \text { Change }\end{array}$ & $\begin{array}{c}\text { Government } \\
\text { Budget } \\
\text { (bn baht) }\end{array}$ & $\begin{array}{c}\text { CPI } \\
\text { \% Change }\end{array}$ & $\begin{array}{l}\text { Stock } \\
\text { Index }\end{array}$ & $\begin{array}{c}\text { Interest } \\
\text { Rate (\%) } \\
\text { short-term }\end{array}$ \\
\hline \multirow{16}{*}{ Thailand } & 1997 & -0.4 & -15.16 & 8.0 & 376.2 & 14.59 \\
\hline & 1998 & -8.0 & -128.95 & 4.3 & 355.8 & 13.02 \\
\hline & 1999 & 0.2 & -154.19 & 7.2 & 391.5 & 3.70 \\
\hline & 2000 & 6.0 & -108.06 & 1.8 & 327.5 & 3.25 \\
\hline & 2001 & 4.2 & -122.99 & 1.3 & 303.5 & 2.75 \\
\hline & 2002 & 6.0 & -102.07 & 0.4 & 353.48 & 2.00 \\
\hline & 2003 & 5.8 & -105.01 & 1.1 & 567.1 & 2.00 \\
\hline & \multicolumn{6}{|c|}{ External Balance } \\
\hline & & $\begin{array}{c}\text { Trade } \\
\text { Balance } \\
\text { US\$bn }\end{array}$ & $\begin{array}{c}\text { Financial } \\
\text { Account } \\
\text { US\$bn }\end{array}$ & $\begin{array}{c}\text { Foreign } \\
\text { Reserves } \\
\text { US\$bn }\end{array}$ & $\begin{array}{c}\text { Currency } \\
\text { per US\$ }\end{array}$ & \\
\hline & 1997 & 1.60 & -5.4 & 26.9 & 47.00 & \\
\hline & 1998 & 13.10 & -9.8 & 29.5 & 41.37 & \\
\hline & 1999 & 10.50 & -7.9 & 34.8 & 37.84 & \\
\hline & 2000 & 5.60 & -10.3 & 32.7 & 40.15 & \\
\hline & 2001 & 2.50 & -5.1 & 33.0 & 44.48 & \\
\hline & 2002 & 3.40 & -4.0 & 38.9 & 43.00 & \\
\hline & 2003 & 4.50 & -7.0 & 39.2 & 40.01 & \\
\hline
\end{tabular}

